\title{
A network meta-analysis of randomized controlled trials of biologics for rheumatoid arthritis: a Cochrane overview
}

\author{
Jasvinder A. Singh MD, Robin Christensen PhD, George A. Wells PhD, Maria E. Suarez-Almazor MD, \\ Rachelle Buchbinder MD, Maria Angeles Lopez-Olivo MD, Elizabeth Tanjong Ghogomu MD, \\ Peter Tugwell MD
}

Previously published at www.cmaj.ca

\section{ABSTRACT}

Background: We sought to compare the benefits and safety of 6 biologics (abatacept, adalimumab, anakinra, etanercept, infliximab and rituximab) in patients with rheumatoid arthritis.

Methods: In this network meta-analysis, we included all completed and updated Cochrane reviews on biologics for rheumatoid arthritis. We included data from all placebocontrolled trials that used standard dosing regimens. The major outcomes were benefit (defined as a $50 \%$ improvement in patient- and physician-reported criteria of the American College of Rheumatology [ACR50]) and safety (determined by the number of withdrawals related to adverse events). We used mixed-effects logistic regression to carry out an indirect comparison of the treatment effects between biologics.

Results: Compared with placebo, biologics were associated with a clinically important higher ACR50 rate (odds ratio [OR] 3.35, 95\% confidence interval [Cl] 2.62-4.29) and a number needed to treat for benefit of $4(95 \% \mathrm{Cl} 4-6)$. However, biologics were associated with more withdrawals related to adverse events (OR 1.39, 95\% Cl 1.13-1.71), with a number needed to treat for harm of 52 (95\% Cl 29-152). Anakinra was less effective than all of the other biologics, although this difference was statistically significant only for the comparison with adalimumab (OR $0.45,95 \% \mathrm{Cl} 0.21-$ 0.99 ) and etanercept (OR $0.34,95 \% \mathrm{Cl} 0.14-0.81)$. Adalimumab, anakinra and infliximab were more likely than etanercept to lead to withdrawals related to adverse events (adalimumab OR 1.89, 95\% Cl 1.18-3.04; anakinra OR 2.05, 95\% Cl 1.27-3.29; and infliximab OR 2.70, 95\% Cl 1.43-5.26).

Interpretation: Given the limitations of indirect comparisons, anakinra was less effective than adalimumab and etanercept, and etanercept was safer than adalimumab, anakinra and infliximab. This summary of the evidence will help physicians and patients to make evidence-based choices about biologics for the treatment of rheumatoid arthritis. heumatoid arthritis is one of the most common types of inflammatory arthritis, affecting $0.5 \%-1.0 \%$ of adults in Western countries. ${ }^{1}$ Rheumatoid arthritis is associated with joint inflammation and destruction, which leads to major decrements in health-related quality of life, ${ }^{2}$ functional limitations and work disability. ${ }^{3,4}$
In the last decade, several biologics have been approved, and their use has revolutionized the treatment of rheumatoid arthritis. These biologics are targeted therapies that dramatically inhibit the progression of joint damage in rheumatoid arthritis. These include inhibitors of tumour necrosis factor ${ }^{5}$ (infliximab, etanercept, adalimumab, certolizumab and golimumab), anti-interleukin 1 therapy (anakinra), anti-CD28 therapy (abatacept) and anti-B-cell therapy (rituximab). Biologics are recommended for use in patients with rheumatoid arthritis who have a suboptimal response or intolerance to traditional disease-modifying antirheumatic drugs, such as methotrexate. Although biologics have typically been compared with placebo, with both groups taking the same dose of methotrexate concomitantly, there have been no large randomized controlled trials comparing the biologics to one another. One randomized controlled trial included 2 biologics but compared both only to placebo and not to each other. Because of the high cost of biologics, different routes and administration schedules and different adverse event profiles, general practitioners and rheumatologists need to know their relative benefits and safety when deciding on treatment.

One previous systematic review compared the benefits and safety of biologics using data from randomized and nonrandomized controlled trials. This review combined both recommended and nonrecommended doses $;{ }^{7}$ it found only one difference: infliximab was superior to anakinra in achieving a 20\% improvement in the American College of Rheumatology response criteria for rheumatoid arthritis (ACR20). Overviews of systematic reviews for comparing and combining different systematic reviews assessing single agents have only recently been adopted by Cochrane. ${ }^{8}$ In the absence of direct

From the Department of Medicine (Singh), Minneapolis VA Medical Center and University of Minnesota, Minneapolis and Mayo Clinic College of Medicine, Rochester, USA; the Parker Institute: Musculoskeletal Statistics Unit (Christensen), Frederiksberg Hospital, Frederiksberg, Denmark; the Cardiovascular Research Reference Centre (Wells), University of Ottawa Heart Institute, Ottawa, Ont.; General Internal Medicine (Suarez-Almazor, LopezOlivo), Ambulatory Treatment and Emergency Care, University of Texas, M.D. Anderson Cancer Center, Houston, USA; the Monash Department of Clinical Epidemiology at Cabrini Hospital (Buchbinder), Department of Epidemiology and Preventive Medicine, Monash University, Malvern, Australia; and the Centre for Global Health (Ghogomu, Tugwell), Institute of Population Health, University of Ottawa, Ottawa, Ont.

Cite as CMAJ 2009. DOI:10.1503/cmaj.091391 
head-to-head comparisons, we performed an overview of the systematic reviews of biologics for rheumatoid arthritis using network meta-analyses of updated Cochrane systematic reviews. We sought to provide estimates of the benefits and safety of biologics to assist patients and clinicians decide between biologics in clinical practice.

\section{Methods}

\section{Selection and quality assessment of reviews}

We searched the Cochrane library for systematic reviews of biologics for rheumatoid arthritis on May 30, 2009, using the search term "rheumatoid arthritis" as the title in the advanced search option. Two authors (J.S. and R.C.) independently selected the reviews from the search. The authors of reviews completed before 2009 were contacted, and all agreed to update their reviews to 2009.

Two authors (J.S. and G.W.) extracted review characteristics, the benefits and safety results, and they assessed the quality of the reviews using the Assessment of Multiple Systematic Reviews (AMSTAR) quality-assessment instrument. ${ }^{9}$

\section{Outcomes}

Two major outcomes were specified a priori: benefit (defined as a 50\% improvement in the American College of Rheumatology symptomatic criteria [ACR50] $)^{10}$ and safety (determined by the number of withdrawals because of adverse events). ACR50 is a validated clinically meaningful binary measure of benefit. It is defined as a 50\% improvement in swollen and tender joint

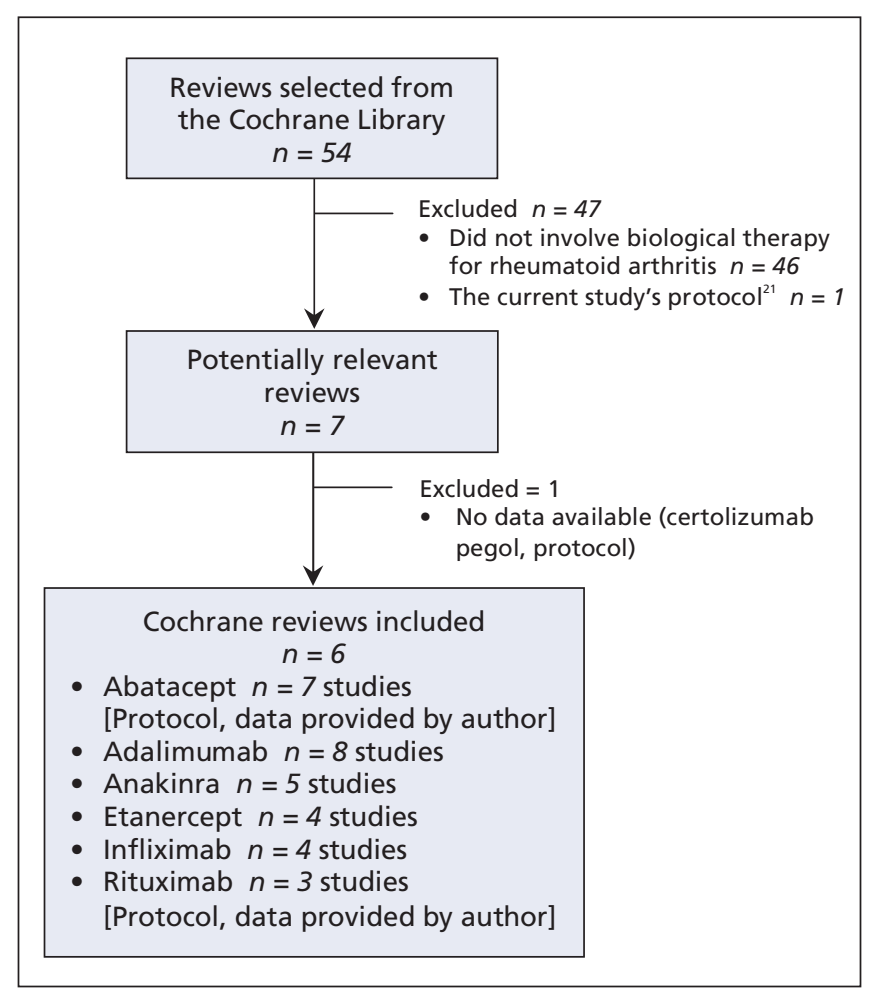

Figure 1: Flow chart for selection of systematic reviews included in the overview of systematic reviews of biologics for treatment of rheumatoid arthritis. counts plus a $50 \%$ improvement in 3 of the following 5 criteria: (1) patient global assessment; (2) physician global assessment; (3) pain score; (4) physical function (Health Assessment Questionnaire score) and (5) laboratory acute phase reactants (erythrocyte sedimentation rate or C-reactive protein level). ${ }^{10}$ For safety, we sought to include specific adverse events; however, these were reported inconsistently. Therefore, we chose to include withdrawals that occurred because of adverse events, which is a measure of patients' tolerance of adverse events and is reported consistently.

Additional prespecified comparisons were the use of concomitant methotrexate versus no methotrexate; duration of rheumatoid arthritis disease (early [ $<2$ years], established [2-10 years] v. late [ $>10$ years]); anti-tumour necrosis factor biologics versus other biologics; failure of traditional diseasemodifying antirheumatic drugs versus biologic failure (or both) versus neither; single biologic agent versus combination biologic therapy; treatment duration (short $[\leq 6$ months $] \mathrm{v}$. intermediate [ $>-12$ months $]$ v. long [> 12 months $]$ ); and previous failure of an anti-tumour necrosis factor biologic.

\section{Statistical analyses}

When 2 drugs are compared with a common standard, the difference in effect between these 2 drugs with respect to the common standard forms the basis of indirect comparisons. In our case, most biologics were used in conjunction with other baseline disease-modifying antirheumatic drugs (most commonly methotrexate, but others in some cases, which leads to clinical heterogeneity) and compared with placebo and the same baseline therapy. Indirect treatment comparisons in meta-analysis can be analyzed by various methods according to the different networks applied, including the star, ladder, closed and partially closed-loop designs. ${ }^{11}$ We used the star design and included 1 active and 1 placebo group from each available trial, independent of concomitant medication use. Individual trial data were used, which were extracted from the available Cochrane reviews.

We performed mixed-effects logistic regression using an arm-based, random-effects model within an empirical Bayes framework. ${ }^{12}$ The generalized linear mixed model incorporates a vector of random effects and a design matrix for the random effects. Allowance is made for differences in heterogeneity of effects between different drugs by specifying that the linear predictor varies at the level of study and the drug across study. We present the inconsistency index $\left(I^{2}\right)$ for each of the drugs compared with placebo (ranging from $0 \%$ to $100 \%$, higher values indicate more heterogeneity). $I^{2}$ is a statistic for quantifying inconsistency of the results in the individual reviews and combines the $\chi^{2}$ statistic and the number of studies contributing to each summary estimate in the figure. We evaluated heterogeneity for the indirect comparison analyses using $\tau^{2}$, which examines heterogeneity because of study and study $\times$ drug interaction (smaller values indicate a better model). There is no specific range for this measure. (For details of the analytic methods, see Appendix 1, available at www.cmaj.ca/cgi/content/full/cmaj.091391/DC1.)

On the basis of the comparison of the individual odds ratio (OR) values to the overall event rate in the placebo groups as 
a proxy for baseline risk, we estimated the number needed to treat for benefit and harm, with $95 \%$ confidence intervals (CIs). This method enables direct translation into clinical practice. ${ }^{13}$ We considered $p$ values less than 0.05 and $95 \%$ CIs that did not include 1 to be statistically significant.

\section{Results}

\section{Description of included reviews}

Of the 54 reviews and protocols identified, 6 Cochrane reviews met the criteria (Figure 1). The reviews included 3 on anti-tumour necrosis factor therapies (etanercept [4 studies], ${ }^{14}$ infliximab [4 studies] ${ }^{15}$ and adalimumab [8 studies] ${ }^{16}$ ) and 1 each of anti-interleukin 1 (anakinra [5 studies]), ${ }^{17}$ anti-B-cell (rituximab [3 studies]) ${ }^{18}$ and anti-CD28 therapy (abatacept [7 studies]). ${ }^{19}$ Eligibility criteria and patient populations were similar across reviews, namely adults with rheumatoid arthritis who met the American College of Rheumatology classification criteria for rheumatoid arthritis ${ }^{20}$ (Table 1). A list of all studies from these 6 reviews included in this overview is provided in Appendix 2 (available at www.cmaj.ca/cgi/content /full/cmaj.091391/DC1). All reviews followed the methods in the Cochrane Handbook, including standardized searches, prespecified inclusion criteria and outcomes (Appendix 3, available at www.cmaj.ca/cgi/content/full/cmaj.091391/DC1). In most randomized controlled trials, each biologic was com- pared with a placebo, usually in combination with traditional disease-modifying antirheumatic drugs (usually methotrexate) or other biologics. All reviews met 8 or more of the 11 of the AMSTAR quality criteria (Appendix 4, available at www .cmaj.ca/cgi/content/full/cmaj.091391/DC1). Additional clinical outcomes of interest are presented in Appendix 5 and Appendix 6 (available at www.cmaj.ca/cgi/content/full /cmaj.091391/DC1) and in the full Cochrane review. ${ }^{21}$

\section{Benefit and safety of biologics versus placebo}

A summary of the findings is presented in Table 2. Of the 31 included studies, 27 reported ACR50 and 29 reported withdrawals because of adverse events. Compared with placebo, the use of biologics was associated with a significantly higher likelihood of achieving an ACR50 response (OR 3.35, 95\% CI 2.62-4.29) and withdrawal related to an adverse event (OR 1.39, 95\% CI 1.13-1.71), albeit with a significant amount of heterogeneity ( $I$ of $69 \%$ and $15 \%$ and $\tau^{2}$ of 0.67 and 0.37 , respectively). Each individual biologic was significantly more likely than placebo to achieve an ACR50 (ORs between 2.92 and 4.97), except for anakinra (OR 1.68, 95\% CI 0.83-3.41) (Figure 2). Withdrawals related to adverse events were significantly higher among patients taking adalimumab, anakinra and infliximab than among those taking a placebo (ORs between 1.54 and 2.21) (Figure 3); however, this was not significantly higher than placebo for abatacept

Table 1: Characteristics of the inclusion criteria and the patient populations of the included reviews

\begin{tabular}{|c|c|c|}
\hline Biologic & Inclusion criteria & Patient populations in the included studies \\
\hline Adalimumab & $\begin{array}{l}\text { - All RCTs or CCTs comparing adalimumab (alone or in } \\
\text { combination with DMARDs) with placebo or other } \\
\text { DMARDs }\end{array}$ & $\begin{array}{l}\text { - Patients who met the } 1987 \text { revised ACR criteria for } \\
\text { rheumatoid arthritis and who had active disease as } \\
\text { defined in each study }\end{array}$ \\
\hline Abatacept & $\begin{array}{l}\text { - All RCTs comparing abatacept (alone or in } \\
\text { combination with DMARDs) with placebo or other } \\
\text { DMARDs; no restrictions on dosage or duration of } \\
\text { the intervention }\end{array}$ & $\begin{array}{l}\text { - Patients aged } 16 \text { years or older who met the } 1987 \\
\text { revised ACR criteria for rheumatoid arthritis }\end{array}$ \\
\hline Anakinra & $\begin{array}{l}\text { - All RCTs comparing anakinra (alone or in } \\
\text { combination with DMARDs or other biologics) with } \\
\text { placebo or other DMARDs or biologics in patients } \\
\text { with rheumatoid arthritis }\end{array}$ & $\begin{array}{l}\text { - Adults aged } 18 \text { years and older who met the } 1987 \\
\text { revised ACR criteria for rheumatoid arthritis }\end{array}$ \\
\hline Etanercept & $\begin{array}{l}\text { - All RCTs or CCTs of at least } 6 \text { months' duration } \\
\text { comparing etanercept with placebo, etanercept with } \\
\text { methotrexate, or etanercept plus methotrexate with } \\
\text { methotrexate alone }\end{array}$ & $\begin{array}{l}\text { - Patients } 16 \text { years of age or older who met the } 1987 \\
\text { revised ACR criteria for rheumatoid arthritis } \\
\text { - Patients with evidence of active disease (at least } 2 \text { of } \\
\text { the following: tender joint count; swollen joint count; } \\
\text { duration of early morning stiffness > } 30 \text { minutes; and } \\
\text { presence of acute phase reactants, such as Westergren } \\
\text { erythrocyte sedimentation rate or C reactive protein) }\end{array}$ \\
\hline Infliximab & $\begin{array}{l}\text { All RCTs comparing infliximab }(1,3,5 \text { or } 10 \mathrm{mg} / \mathrm{kg}) \\
\text { plus methotrexate with methotrexate alone, or } \\
\text { infliximab with placebo, with a minimum duration } \\
\text { of } 6 \text { months and at least } 2 \text { infusions }\end{array}$ & $\begin{array}{l}\text { - Patients } 16 \text { years and older who met the } 1987 \text { revised } \\
\text { ACR criteria for rheumatoid arthritis } \\
\text { - Patients with evidence of active disease (at least } 2 \text { of } \\
\text { the following: tender joint count; swollen joint count; } \\
\text { duration of early morning stiffness }>30 \text { min; and } \\
\text { acute phase reactants, such as erythrocyte } \\
\text { sedimentation rate or C reactive protein) }\end{array}$ \\
\hline Rituximab & $\begin{array}{l}\text { - All RCTs comparing rituximab (300, 350, } 500 \text { or } \\
600 \mathrm{mg} / \mathrm{m}^{2} \text { ) (alone or in combination with DMARD) } \\
\text { with placebo or other DMARDs or biologic }\end{array}$ & $\begin{array}{l}\text { - Patients } 16 \text { years and older who met the } 1987 \text { revised } \\
\text { ACR criteria for rheumatoid arthritis and who had } \\
\text { active disease as described by the authors }\end{array}$ \\
\hline
\end{tabular}

Note: $\mathrm{ACR}=$ American College of Rheumatology, $\mathrm{CCT}=$ controlled clinical trial, DMARD = disease-modifying antirheumatic drug, RCT $=$ randomized controlled trial 
and rituximab. Etanercept had a minimally lower nonsignificant withdrawal rate than did placebo (OR 0.82, 95\% CI 1.28-3.82). Heterogeneity for ACR50, as measured by the $I^{2}$ statistic, ranged from $0 \%$ to $17 \%$ (i.e., low or unimportant) for abatacept, infliximab and rituximab and from $75 \%$ to $84 \%$ (i.e., substantial) for anakinra, adalimumab and etanercept. The $I^{2}$ for withdrawals related to adverse events ranged from $0 \%$ to $15 \%$ (i.e., low or unimportant) for abatacept, adalimumab, anakinra and rituximab and from $55 \%$ to $94 \%$ (i.e., substantial) for etanercept and infliximab.

Table 2: Summary of the findings of meta-analyses of biologics for rheumatoid arthritis

\begin{tabular}{|c|c|c|c|c|c|c|c|}
\hline $\begin{array}{l}\text { Outcome; } \\
\text { biologic }\end{array}$ & $\begin{array}{c}\text { Intervention and } \\
\text { comparison } \\
\text { intervention }\end{array}$ & $\begin{array}{l}\text { Assumed } \\
\text { risk }^{\mathrm{b}} \text { with } \\
\text { comparator, per } \\
1000 \text { patients }\end{array}$ & $\begin{array}{l}\text { Corresponding risk } \\
\text { with comparator, } \\
\text { per } 1000 \text { patients } \\
(95 \% \mathrm{Cl})\end{array}$ & $\begin{array}{c}\text { Relative } \\
\text { effect, } \\
\text { OR }(95 \% \mathrm{Cl})\end{array}$ & $\begin{array}{l}\text { No. of } \\
\text { participants }\end{array}$ & $\begin{array}{l}\text { Quality of } \\
\text { evidence } \\
\text { (GRADE) }\end{array}$ & $\begin{array}{l}\text { Number } \\
\text { needed to } \\
\text { treat } \\
(95 \% \mathrm{Cl})\end{array}$ \\
\hline \multicolumn{8}{|l|}{ Benefit } \\
\hline Abatacept & $\begin{array}{c}\text { Abatacept }+ \\
\text { DMARD or biologic } \\
\text { v. placebo }+ \\
\text { DMARD or biologic }\end{array}$ & 207 & $\begin{array}{c}437 \\
(319-565)\end{array}$ & $\begin{array}{c}2.98 \\
(1.79-4.97)\end{array}$ & $\begin{array}{c}1712 \\
\left(6 \text { studies }^{22-27}\right)\end{array}$ & Moderate $^{d}$ & $4(3-9)$ \\
\hline Adalimumab & $\begin{array}{c}\text { Adalimumab } \pm \\
\text { DMARD or biologic } \\
\text { V. placebo } \pm \\
\text { DMARD or biologic }\end{array}$ & 207 & $\begin{array}{c}491 \\
(385-598)\end{array}$ & $\begin{array}{c}3.70 \\
(2.40-5.70)\end{array}$ & $\begin{array}{c}2269 \\
\left(8 \text { studies }^{28-35}\right)\end{array}$ & Moderate & $4(3-6)$ \\
\hline Anakinra & $\begin{array}{c}\text { Anakinra } \pm \\
\text { DMARD or biologic } \\
\text { V. placebo } \pm \\
\text { DMARD or biologic }\end{array}$ & 207 & $\begin{array}{c}304 \\
(178-472)\end{array}$ & $\begin{array}{c}1.68 \\
(0.83-3.41)\end{array}$ & $\begin{array}{c}815 \\
\left(3 \text { studies }^{36-38}\right)\end{array}$ & Moderate $^{f}$ & NS \\
\hline Etanercept & $\begin{array}{c}\text { Etanercept } \pm \\
\text { DMARD } \\
\text { v. placebo } \pm \text { DMARD }\end{array}$ & 207 & $\begin{array}{c}565 \\
(414-704)\end{array}$ & $\begin{array}{c}4.97 \\
(2.70-9.13)\end{array}$ & $\begin{array}{c}1205 \\
\left(4 \text { studies }^{39-42}\right)\end{array}$ & Moderate $^{g}$ & $3(2-5)$ \\
\hline Infliximab & $\begin{array}{l}\text { Infliximab + DMARD } \\
\text { v. placebo + DMARD }\end{array}$ & 207 & $\begin{array}{c}433 \\
(263-619)\end{array}$ & $\begin{array}{c}2.92 \\
(1.37-6.24)\end{array}$ & $\begin{array}{c}819 \\
\left(3 \text { studies }^{43-45}\right)\end{array}$ & High & $4(2-18)$ \\
\hline Rituximab & $\begin{array}{l}\text { Rituximab + DMARD } \\
\text { v. placebo + DMARD }\end{array}$ & 207 & $\begin{array}{c}518 \\
(346-1000)\end{array}$ & $\begin{array}{c}4.10 \\
(2.02-8.33)\end{array}$ & $\begin{array}{c}823 \\
\left(3 \text { studies }^{46-48}\right)\end{array}$ & Moderate $^{h}$ & $3(1-7)$ \\
\hline \multicolumn{8}{|l|}{ Safety } \\
\hline Abatacept & $\begin{array}{c}\text { Abatacept }+ \\
\text { DMARD or biologic } \\
\text { v. placebo }+ \\
\text { DMARD or biologic }\end{array}$ & 54 & $\begin{array}{c}66 \\
(48-91)\end{array}$ & $\begin{array}{c}1.24 \\
(0.88-1.76)\end{array}$ & $\begin{array}{c}1441 \\
\left(6 \text { studies }^{22-27}\right)\end{array}$ & Moderate $^{d}$ & NS \\
\hline Adalimumab & $\begin{array}{c}\text { Adalimumab } \pm \\
\text { DMARD or biologic } \\
\text { v. placebo } \pm \\
\text { DMARD or biologic }\end{array}$ & 54 & $\begin{array}{c}81 \\
(60-108)\end{array}$ & $\begin{array}{c}1.54 \\
(1.12-2.12)\end{array}$ & $\begin{array}{c}2944 \\
\left(8 \text { studies }^{28-35}\right)\end{array}$ & $\operatorname{Low}^{e, i}$ & $39(19-162)$ \\
\hline Anakinra & $\begin{array}{c}\text { Anakinra } \pm \\
\text { DMARD or biologic } \\
\text { v. placebo } \pm \\
\text { DMARD or biologic }\end{array}$ & 54 & $\begin{array}{c}87 \\
(65-116)\end{array}$ & $\begin{array}{c}1.67 \\
(1.22-2.29)\end{array}$ & $\begin{array}{c}2619 \\
\left(5 \text { studies }^{36-38,49,50}\right)\end{array}$ & Moderate $^{f}$ & $31(17-92)$ \\
\hline Etanercept & $\begin{array}{c}\text { Etanercept } \pm \\
\text { DMARD } \\
\text { v. placebo } \pm \text { DMARD }\end{array}$ & 54 & $\begin{array}{c}45 \\
(31-64)\end{array}$ & $\begin{array}{c}0.82 \\
(0.56-1.19)\end{array}$ & $\begin{array}{c}1248 \\
\left(4 \text { studies }^{39-42}\right)\end{array}$ & Moderate $^{g}$ & NS \\
\hline Infliximab & $\begin{array}{l}\text { Infliximab + DMARD } \\
\text { v. placebo + DMARD }\end{array}$ & 54 & $\begin{array}{c}112 \\
(68-179)\end{array}$ & $\begin{array}{c}2.21 \\
(1.28-3.82)\end{array}$ & $\begin{array}{c}835 \\
\left(3 \text { studies }^{43-45}\right)\end{array}$ & High & $18(8-72)$ \\
\hline Rituximab & $\begin{array}{l}\text { Rituximab + DMARD } \\
\text { v. placebo + DMARD }\end{array}$ & 54 & $\begin{array}{c}71 \\
(36-136)\end{array}$ & $\begin{array}{c}1.34 \\
(0.65-2.76)\end{array}$ & $\begin{array}{c}938 \\
\left(3 \text { studies }^{46-48}\right)\end{array}$ & Moderate $^{h}$ & NS \\
\hline
\end{tabular}

Note: $\mathrm{Cl}=$ confidence interval, DMARD = disease-modifying antirheumatic drug, NS = not significant, OR = odds ratio.

${ }^{a}$ Benefit is defined as a $50 \%$ improvement in American College of Rheumatology symptomatic criteria (ACR50); safety is determined by the number of withdrawls related to adverse events.

${ }^{\mathrm{b}}$ The assumed risk is based on the empirical control event rate across all drugs and all studies.

'The corresponding risk (and its $95 \% \mathrm{Cl}$ ) is based on the assumed risk in the comparison group and the relative effect of the intervention (and its $95 \% \mathrm{Cl}$ ).

Intention-to-treat analysis not performed in one study: ${ }^{26} 9$ patients in abatacept group and 5 in control group were not included in the analysis.

${ }^{e}$ Randomization and blinding were not described and allocation concealment was not clear in 7 studies. $^{29-35}$

${ }^{f}$ Randomization not described in all 4 studies; intention to treat analysis not performed in 3 studies; ${ }^{37,38,49}$ blinding not described and $>20 \%$ dropout in 1 study; ${ }^{36}$ allocation concealment not described in 1 study. ${ }^{38}$

${ }^{9}$ Randomization not described in 1 study; ${ }^{42}$ allocation concealment and blinding not described in 1 study. ${ }^{41}$

${ }^{\mathrm{h}}$ Randomization and allocation concealment not described in all 3 studies; blinding not clear in 1 study; ${ }^{47}$ attrition not clear in 1 study.

'Analysis included nonstandard doses. 


\section{Number needed to treat}

The control event rate in the placebo group was $20.7 \%$ for ACR50 and $5.4 \%$ for withdrawal because of adverse events. The numbers needed to treat for benefit and harm were not adjusted for prevalence because these trials reflected the types of patients eligible for biologic therapy. The numbers needed to treat for benefit were 3 (95\% CI 3-5) for etanercept, 4 (95\% CI 3-6) for adalimumab, 4 for (95\% CI 3-8) for rit- uximab, 5 (95\% CI 3-10) for abatacept and infliximab, and 5 (95\% CI 3-18) for infliximab. For anakinra, the number needed to treat for a benefit was not significant.

The number needed to treat for harm (withdrawals related to adverse events compared with placebo) was 39 (95\% CI 19-162) for adalimumab, 31 (95\% CI 17-92) for anakinra and 18 (95\% CI 8-72) for infliximab. The numbers needed to treat for harm for abatacept, etanercept and rituximab were not significant.

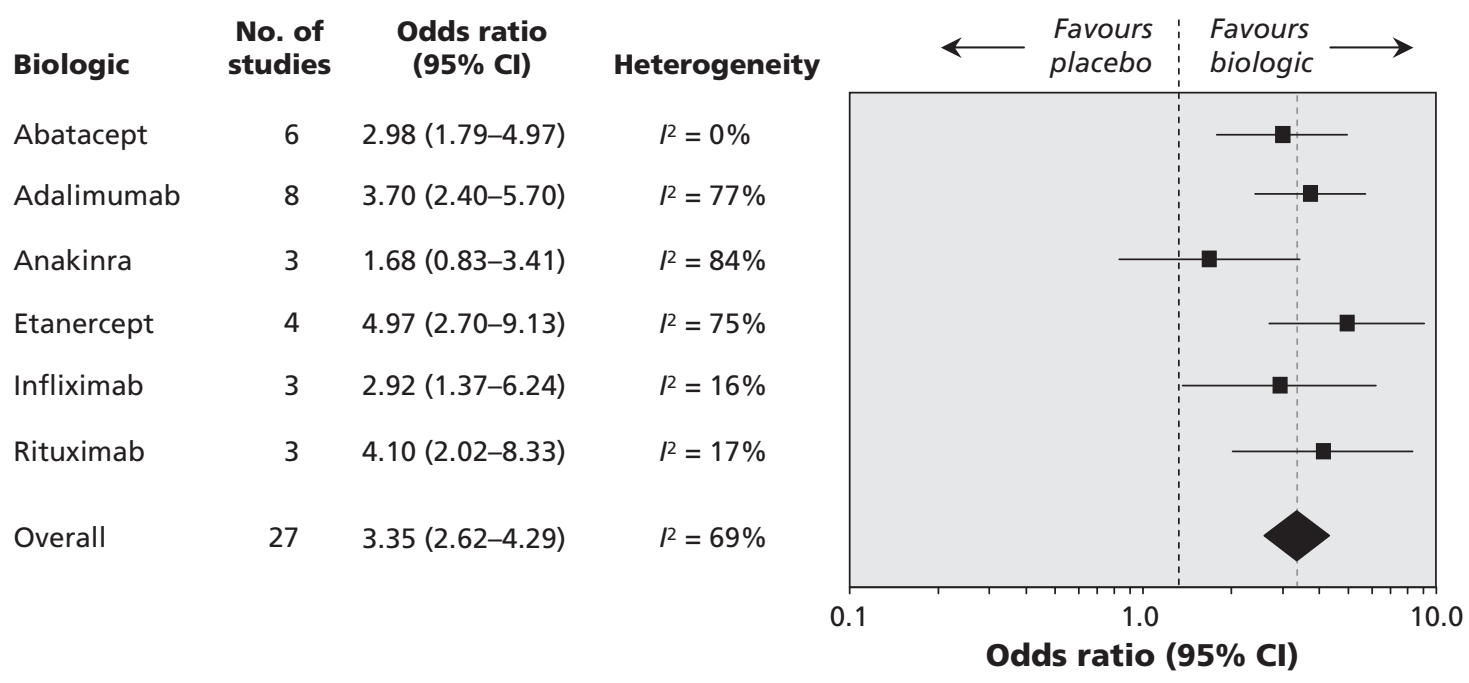

Figure 2: Comparison of each biologic to placebo for benefit (defined as a $50 \%$ improvement in patient- and physician-reported criteria of the American College of Rheumatology [ACR50]). A value greater than 1.0 indicates a benefit from the biologic. $\mathrm{Cl}=\mathrm{confidence}$ interval. For details of studies included for each biologic, refer to Appendix 2 (avaiable at www.cmaj.ca/cgi/content/full /cmaj.091391/DC1).

\begin{tabular}{|c|c|c|c|c|c|c|c|}
\hline Biologic & $\begin{array}{l}\text { No. of } \\
\text { studies }\end{array}$ & $\begin{array}{c}\text { Odds ratio } \\
(95 \% \mathrm{Cl})\end{array}$ & Heterogeneity & $\longleftarrow$ & $\begin{array}{l}\text { Favours } \\
\text { biologic }\end{array}$ & $\begin{array}{l}\text { Favours } \\
\text { placebo }\end{array}$ & \\
\hline Abatacept & 6 & $1.24(0.88-1.76)$ & $R^{2}=15 \%$ & & & & \\
\hline Adalimumab & 8 & $1.54(1.12-2.12)$ & $R^{2}=0 \%$ & & & & \\
\hline Anakinra & 5 & $1.67(1.22-2.29)$ & $R^{2}=0 \%$ & & & & \\
\hline Etanercept & 4 & $0.82(0.56-1.19)$ & $R^{2}=94 \%$ & & & & \\
\hline Infliximab & 3 & $2.21(1.28-3.82)$ & $R^{2}=55 \%$ & & & 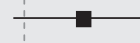 & \\
\hline Rituximab & 3 & $1.34(0.65-2.76)$ & $R^{2}=0 \%$ & & & 0 & \\
\hline Overall & 29 & $1.39(1.13-1.71)$ & $R^{2}=15 \%$ & & & & \\
\hline & & & \multicolumn{2}{|c|}{0.1} & Odds ra & (95\% Cl) & 10.0 \\
\hline
\end{tabular}

Figure 3: Comparison of each biologic to placebo for safety (deterined by number of withdrawals because of adverse events). A value less than 1.0 indicates a benefit from the biologic. $\mathrm{Cl}=$ confidence interval. For details of the studies included for each biologic, refer to Appendix 2 (avaiable at www.cmaj.ca/cgi/content/full/cmaj.091391/DC1). 


\section{Indirect comparison of treatment effects between biologics}

Anakinra was less effective than adalimumab $(p=0.046)$ and etanercept ( $p=0.015$ ) in achieving ACR50 (Figure 4). There were significantly fewer withdrawals related to adverse events among patients taking etanercept than among those taking adalimumab $(p=0.009)$, anakinra $(p=0.003)$ or infliximab $(p=0.002)$ (Figure 5).

\section{Subgroup analyses}

In 5 of 7 subgroup analyses, biologics were significantly more effective than placebo in achieving ACR50 for all subgroups analyzed (Table 3). Biologics were similarly effective regardless of concomitant methotrexate use (yes v. no), mean duration of rheumatoid arthritis, type of drug previously failed (disease-modifying antirheumatic drugs v. biologic and disease-modifying antirheumatic drugs v. none), whether antitumour necrosis factor biologics had previously failed or whether the biologic used targeted tumour necrosis factor versus other cells or targets. The use of a single biologic, but not combination biologic therapy, was associated with significantly more benefit than placebo. Similarly, biologics were significantly more effective than placebo in randomized controlled trials of short and intermediate duration but not long duration.

For withdrawals related to adverse events, there were no differences among patients who used concomitant methotrexate (v. no use) or for whom anti-tumour necrosis factor biologics had previously failed (Table 3 ). We could not obtain estimates for the use of combination biologics versus a single biologic. Biologics were significantly more likely than placebo to lead to withdrawal related to an adverse event among patients with late rheumatoid arthritis but not early or established rheumatoid arthritis. Non-anti-tumour necrosis factor biologics were more likely than placebo to lead to withdrawal related to an adverse event. Compared with placebo, biologics were associated with a higher rate of withdrawal related to adverse events among patients in whom traditional disease-modifying antirheumatic drug or biologic (or both) therapy had previously failed, but not among those who had never taken a disease-modifying antirheumatic drugs. Biologics led to more withdrawals related to adverse events than did placebo in short-term trials, but not in intermediateor long-term trials.

\section{Interpretation}

This is the first overview of updated Cochrane systematic reviews of biologics at the approved doses for rheumatoid arthritis. We systematically extracted data from the existing reviews, updated older reviews to May 2009 and performed a network meta-analysis in accordance with the 2008 Cochrane Handbook. ${ }^{8}$

We made 2 observations that add to current knowledge and deserve further discussion. First, these network indirect comparisons confirm the lower rates of benefit (compared with placebo) with anakinra than with other biologics. Second,

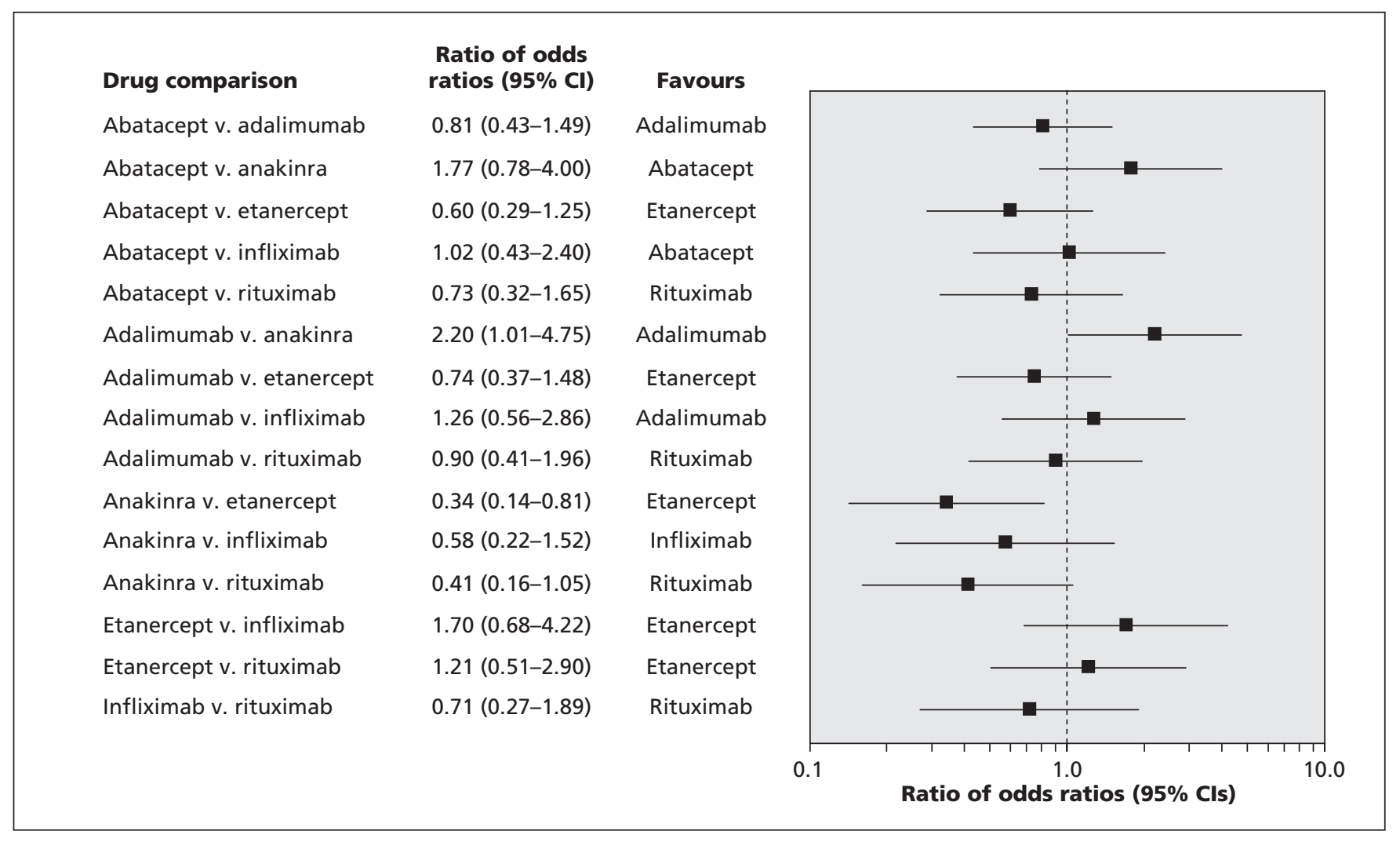

Figure 4: Indirect comparison of each biologic to each other for benefit (ACR50). A value greater than 1.0 indicate a benefit from the biologic. $\mathrm{Cl}=$ confidence interval. $R^{2}$ values for the studies are presented in Figure 2 . 
these analyses confirm the higher rate of withdrawals because of adverse events with infliximab, anakinra and adalimumab compared with placebo or etanercept (indirect comparison).

Physicians and patients must choose among these expensive medications while not knowing which biologic is more effective and safe. Because all 5 biologics examined, excluding anakinra, seemed equally efficacious in terms of relative measures, the choice may depend on cost to patients and health care systems, frequency of administration (e.g., etanercept taken twice weekly v. adalimumab taken every other week), preferences for route of administration (subcutaneous injection for etanercept and adalimumab; intravenous administration for abatacept, infliximab and rituximab) and safety aspects (etanercept was associated with a lower rate of withdrawals because of adverse events than were adalimumab, anakinra or infliximab).

\section{Limitations}

This overview has some limitations. These biologics have been available only for a few years, and the duration of the trials was too short to assess the long-term benefits and harms. Furthermore, delayed and rare effects would not be detected by these controlled trials. The placebo group was somewhat heterogeneous because of the continuing use of disease-modifying antirheumatic drugs for some patients and the use of methotrexate versus other disease-modifying antirheumatic drugs versus another biologic in some studies. ${ }^{50,51}$ Methotrexate is the standard of care for treatment of rheumatoid arthritis, and most randomized controlled trials currently examine new therapies in patients who are taking methotrexate.

The included reviews consist of randomized controlled trials that differed in patient population characteristics, such as the duration of rheumatoid arthritis disease, prior failed therapy, concomitant methotrexate use and trial duration. For some reviews and subsequent stratified analyses, we were limited in that only 3-5 studies were available, which made our analyses susceptible to type II error (i.e., missing a difference when one exists because of small sample size). Thus, even though we performed indirect comparisons of the 6 biologics to each other using valid statistical approaches, these results should be interpreted with caution. The findings from the stratified and subgroup analyses are hypothesis-generating at best, susceptible to type II error with 2 studies each for comparisons of disease-modifying antirheumatic drugs, use of multiple biologics and long-term trial duration. It is reassuring that both patients with and without methotrexate use and those for whom previous biologic treatment had failed or succeeded responded better to biologics than to placebo.

\section{Comparisons with other studies}

The lower benefit of anakinra compared with anti-tumour necrosis factor biologics in indirect comparisons in our study confirms similar findings from a previous meta-analysis ${ }^{7}$ and a qualitative review..$^{52}$ Our estimates of the number needed to treat for ACR50 were similar to those reported earlier ${ }^{53,54}$ from

\section{Drug comparison}

Abatacept v. adalimumab

Abatacept v. anakinra

Abatacept v. etanercept

Abatacept v. infliximab

Abatacept v. rituximab

Adalimumab v. anakinra

Adalimumab v. etanercept

Adalimumab v. infliximab

Adalimumab v. rituximab

Anakinra v. etanercept

Anakinra v. infliximab

Anakinra v. rituximab

Etanercept v. infliximab

Etanercept v. rituximab

Infliximab v. rituximab

$\begin{array}{cc}\begin{array}{c}\text { Ratio of odds } \\ \text { ratios (95\% Cl) }\end{array} & \text { Favours } \\ 0.80(0.51-1.26) & \text { Abatacept } \\ 0.74(0.47-1.17) & \text { Abatacept } \\ 1.52(0.93-2.49) & \text { Etanercept } \\ 0.56(0.30-1.05) & \text { Abatacept } \\ 0.93(0.43-2.02) & \text { Abatacept } \\ 0.92(0.60-1.42) & \text { Adalimumab } \\ 1.89(1.18-3.04) & \text { Etanercept } \\ 0.70(0.38-1.28) & \text { Adalimumab } \\ 1.15(0.54-2.48) & \text { Rituximab } \\ 2.05(1.27-3.29) & \text { Etanercept } \\ 0.76(0.41-1.39) & \text { Anakinra } \\ 1.25(0.58-2.69) & \text { Rituximab } \\ 0.37(0.19-0.70) & \text { Etanercept } \\ 0.61(0.28-1.35) & \text { Etanercept } \\ 1.66(0.69-3.98) & \text { Rituximab }\end{array}$

Ratio of odds
ratios $(95 \% \mathrm{CI})$

$0.80(0.51-1.26)$

1.52 (0.93-2.49)

$0.93(0.43-2.02)$

$1.89(1.18-3.04)$

$0.70(0.38-1.28)$

1.15 (0.54-2.48)

2.05 (1.27-3.29)

$1.25(0.58-2.69)$

37 (0.19-0.70)

$1.66(0.69-3.98)$

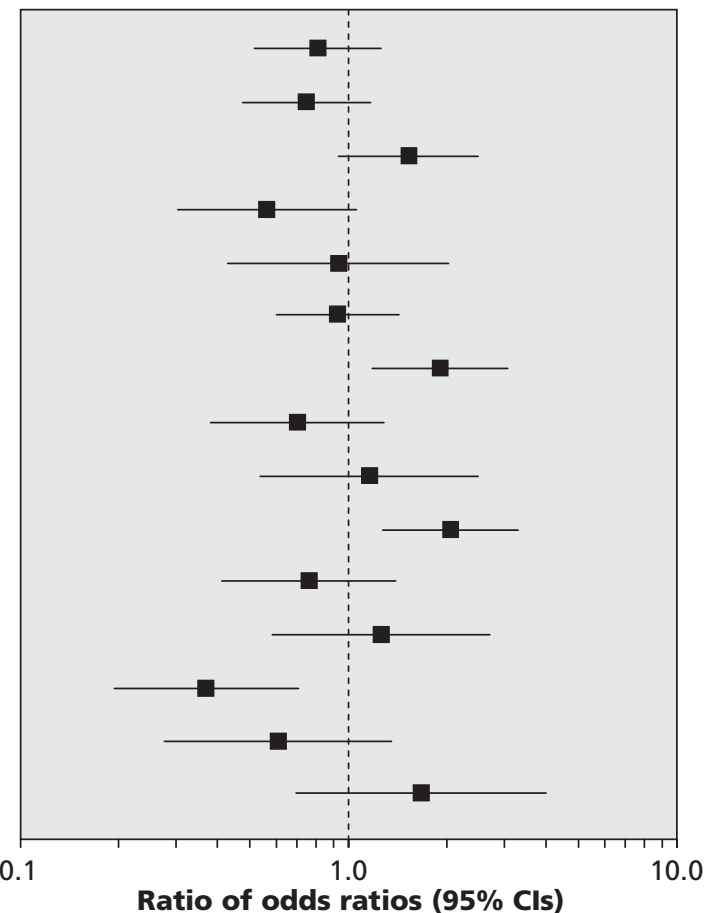

Figure 5: Indirect comparison of biologics to each other for safety (determined by number of withdrawals because of adverse events). A value greater than 1.0 indicate a benefit from the biologic. $\mathrm{Cl}=$ confidence interval. $\mathcal{R}$ values for the studies are presented in Figure 2 . 
Table 3: Stratified meta-analyses for benefit and safety for biologics used in the treatment of rheumatoid arthritis

\begin{tabular}{|c|c|c|c|c|c|c|c|c|}
\hline \multirow[b]{2}{*}{ Group } & \multicolumn{4}{|c|}{ Benefit* } & \multicolumn{4}{|c|}{ Safety† } \\
\hline & $\begin{array}{l}\text { No. of } \\
\text { trials }\end{array}$ & OR $(95 \% \mathrm{Cl})$ & $\begin{array}{c}\tau^{2} \\
\text { (study) } \ddagger\end{array}$ & $\begin{array}{l}\tau^{2} \text { (study } \\
\times \text { drug) } \ddagger\end{array}$ & $\begin{array}{l}\text { No. of } \\
\text { trials }\end{array}$ & OR $(95 \% \mathrm{Cl})$ & $\begin{array}{c}\tau^{2} \\
\text { (study) } \ddagger\end{array}$ & $\begin{array}{l}\tau^{2} \text { (study } \\
\times \text { drug) } \neq\end{array}$ \\
\hline $\begin{array}{l}\text { Concomitant use of } \\
\text { methotrexate }\end{array}$ & & & 0.40 & 0.14 & & & 0.33 & 0.04 \\
\hline Yes & 20 & $3.16(2.40-4.16)$ & & & 21 & $1.30(1.02-1.65)$ & & \\
\hline No & 7 & $4.18(2.48-7.06)$ & & & 8 & $1.70(1.12-2.57)$ & & \\
\hline $\begin{array}{l}\text { Rheumatoid arthritis } \\
\text { duration }\end{array}$ & & & 0.23 & 0.12 & & & 0.34 & 0.04 \\
\hline Early & 5 & $2.05(1.24-3.38$ & & & 5 & $1.45(0.92-2.28)$ & & \\
\hline Established & 8 & $3.47(2.26-5.33)$ & & & 9 & $1.25(0.87-1.78)$ & & \\
\hline Late & 14 & $4.02(2.89-5.59)$ & & & 15 & $1.52(1.09-2.11)$ & & \\
\hline Biologic is TNF-inhibitor & & & 0.45 & 0.14 & & & 0.27 & 0.05 \\
\hline Yes & 15 & $3.57(2.57-4.97)$ & & & 15 & $1.27(0.94-1.69)$ & & \\
\hline No & 12 & $3.10(2.12-4.53)$ & & & 14 & $1.55(1.14-2.11)$ & & \\
\hline Prior drugs failed & & & 0.33 & 0.15 & & & 0.32 & 0.04 \\
\hline Biologic & 5 & $4.09(2.17-7.69)$ & & & 5 & $1.74(1.02-2.96)$ & & \\
\hline DMARD & 20 & $3.27(2.46-4.35)$ & & & 22 & $1.41(1.11-1.79)$ & & \\
\hline None & 2 & $3.00(1.11-8.13)$ & & & 2 & $0.85(0.41-1.76)$ & & \\
\hline Combination biologic therapy & & & 0.57 & 0.09 & & & 0.28 & 0.04 \\
\hline Yes & 2 & $1.00(0.45-2.23)$ & & & 2 & & & \\
\hline No & 25 & $3.60(2.89-4.49)$ & & & 27 & NE & NE & NE \\
\hline Duration of randomized trial & & & 0.29 & 0.13 & 18 & & & \\
\hline Short & 17 & $4.03(2.93-5.54)$ & & & 9 & $1.46(1.07-1.99)$ & & \\
\hline Intermediate & 8 & $2.92(1.91-4.46)$ & & & 2 & $1.31(0.94-1.82)$ & & \\
\hline Long & 2 & $1.73(0.78-3.82)$ & & & & $1.47(0.71-3.03)$ & & \\
\hline Prior failure of TNF biologic & & & 0.45 & 0.14 & & & 0.29 & 0.05 \\
\hline Yes & 5 & $4.11(2.21-7.63)$ & & & 5 & $1.76(1.01-3.06)$ & & \\
\hline No & 22 & $3.24(2.48-4.22)$ & & & 24 & $1.34(1.06-1.69)$ & & \\
\hline
\end{tabular}

Note: DMARD = disease-modifying antirheumatic drug, NE = not estimable, OR $=$ odds ratio, RA $=$ rheumatoid arthritis, $\mathrm{TNF}=$ tumor necrosis factor .

*Defined as $50 \%$ improvement in American College of Rheumatology symptomatic criteria (ACR50).

†As measured by number of withdrawls related to adverse events.

$\ddagger$ Tau-squared $\left(\tau^{2}\right)$ is the measure of heterogeneity between various drugs. Tau-squared is presented as that which is due to study and due to

study $\times$ drug interaction. The overall $\tau^{2}$ is the sum of the $\tau^{2}$ due to study and that due to study $\times$ drug interaction. For example, the overall $\tau^{2}$ for ACR50

for the use of methotrexate background therapy is $0.40+0.14=0.54$.

simple estimation from the placebo trials, thus adding to the robustness of these estimates

Two meta-analyses of randomized controlled trials of all doses of biologics found no significant differences in the ACR50 rates between 4 biologics (etanercept, infliximab, anakinra, adalimumab) in randomized controlled trials that lasted for 6 or more months $s^{55}$ and between all 6 biologics ${ }^{7}$ using indirect comparisons. In contrast, the ACR50 rate was significantly lower for etanercept than for adalimumab $(p<0.0001)$ in one study that included only 3 randomized controlled trials of $\geq 50$-week duration in an analysis that used a modified Bucher approach (i.e., an approach that only implicitly adjusts for varying placebo response rates across trials). ${ }^{56}$

Our findings of significantly higher ACR50 rates with etanercept and adalimumab than with anakinra disagree slightly with previous reports. ${ }^{7,55}$ The difference is likely because of our inclusion of 3-14 more studies for efficacy and 11 more studies for safety (up to May 2009, compared with $2006^{7}$ and $2005^{55}$ ), limiting our analyses to approved doses and the inclusion of all 6 biologics used commonly to treat rheumatoid arthritis.

Our findings of significantly lower rates of withdrawals because of adverse events with etanercept than with adalimumab, anakinra or infliximab add to the current findings and confirm a similar observation in a previous study. ${ }^{56}$ Withdrawals related to adverse events were lower with etanercept than with adalimumab (relative risk $0.38,95 \% \mathrm{CI}$ $0.17-0.86, p=0.02$ ) in a meta-analysis of 3 randomized controlled trials. ${ }^{56}$ No differences were reported between the 6 biologics when data from randomized controlled trials were combined with the observational data gathered by Gartlehner and colleagues. 


\section{Conclusion}

Our overview provides indirect comparisons of the benefit and safety of 6 biologics for rheumatoid arthritis from doubleblind, placebo-controlled trials in the absence of head-to-head studies. Because of differences in the study population characteristics between the trials, these findings must be interpreted with caution. There is a need for longer comparative effectiveness studies of biologics to provide data about the relative and absolute benefit and safety of biologics during various stages of rheumatoid arthritis (early, established and late), the various levels of functional limitation (mild, moderate and severe limitation) and the nature of prior treatment (traditional diseasemodifying antirheumatic drugs v. biologics v. both). This information will help patients and clinicians make informed decisions about these therapies in the ever expanding area of new, effective therapies for rheumatoid arthritis.

\section{This article has been peer reviewed.}

Competing interests: Jasvinder Singh has received speaker fees from Abbott, research and travel grants from Takeda, Savient, Wyeth and Amgen and consultant fees from Savient and URL Pharma. Robin Christensen and George Wells have received research grants and consultant fee from Bristol-Myers Squibb and Abbott. Maria Suarez-Almazor has received speaker fees from Bristol-Myers Squibb and Roche and consultant fees from Amgen. Rachelle Buchbinder is chief investigator of the Australian Rheumatology Association Database (ARAD), which is funded by an enabling grant from the Australian National Health and Medical Research Council and by Monash University. The Australian Rheumatology Association currently receives educational grants from Abbott Australasia Pty Ltd, Roche Products Pty Ltd and Wyeth Australia Pty Ltd and has previously received educational grants from Amgen Australia Pty Ltd, Aventis and Schering Plough in support of ARAD. Peter Tugwell has received consultant fees from Bristol Myers, Chiltern International and UCB Pharmaceuticals. No competing interests declared by Maria Angeles Lopez-Olivo or Elizabeth Tanjong Ghogomu.

Disclaimer: George Wells, CMAJ biostatistical consultant, and Peter Tugwell, chair of the CMAJ Oversight Committee, are coauthors of this article. They were not involved in the vetting of the manuscript before its acceptance.

Contributors: All of the authors contributed to the study conception and design or acquisition of data, or the analysis and interpretation of data and drafted the article or revised it critically for important intellectual content. All of the authors approved the final version submitted for publication. Jasvinder Singh, Robin Christensen and George Wells contributed to protocol development. Jasvinder Singh, Robin Christensen, Rachelle Buchbinder, Maria Angeles Lopez-Olivo, Peter Tugwell, George Wells and Elizabeth Tanjong Ghogomu contributed to protocol editing. Jasvinder Singh, Robin Christensen, Maria Angeles LopezOlivo, George Wells and Elizabeth Tanjong Ghogomu contributed to data extraction, and Jasvinder Singh, Robin Christensen, George Wells and Elizabeth Tanjong Ghogomu contributed to data analysis.

Acknowledgements: The authors thank the authors of the Cochrane systematic reviews of the biologics who provided us with the review data and the updates. They also thank Lara Maxwell for her help in extracting data and analysis regarding secondary outcomes.

Funding: Jasvinder Singh is supported by a US National Institutes of Health Center for Clinical and Translational Science Award (no. 1 KL2 RR02415101). Robin Christensen is supported by the Parker Institute, Musculoskeletal Statistics Unit, and the Oak Foundation, Switzerland. Rachelle Buchbinder is partially supported by an Australian National Health and Medical Research Council Practitioner Fellowship.

\section{REFERENCES}

1. Kvien TK. Epidemiology and burden of illness of rheumatoid arthritis. Pharmacoeconomics 2004;22:1-12.

2. Kvien TK, Uhlig T. Quality of life in rheumatoid arthritis. Scand J Rheumatol 2005;34:333-41.
3. Odegard S, Finset A, Kvien TK, et al. Work disability in rheumatoid arthritis is predicted by physical and psychological health status: a 7-year study from the Oslo RA register. Scand J Rheumatol 2005;34:441-7.

4. Yelin E. Work disability in rheumatic diseases. Curr Opin Rheumatol 2007;19:91-6.

5. Scott DL, Kingsley GH. Tumor necrosis factor inhibitors for rheumatoid arthritis. N Engl J Med 2006;355:704-12.

6. Schiff M, Keiserman M, Codding C, et al. Efficacyand safety of abatacept or infliximab vs placebo in ATTEST: a phase III, multi-centre, randomised, doubleblind, placebo-controlled study in patients with rheumatoid arthritis and an inadequate response to methotrexate. Ann Rheum Dis 2008;67:1096-103.

7. Gartlehner G, Hansen RA, Jonas BL, et al. The comparative efficacy and safety of biologics for the treatment of rheumatoid arthritis: a systematic review and metaanalysis. J Rheumatol 2006;33:2398-408.

8. Becker LA, Oxman AD. Overviews of reviews. In: Higgins JP, Green S, editors Cochrane handbook for systematic reviews of interventions. Version 5.0.1 (updated Sept 2008). Cochrane Collaboration; 2008. Available: www.cochrane-handbook.org (accessed 2009 Oct. 13)

9. Shea BJ, Grimshaw JM, Wells GA, et al. Development of AMSTAR: a measurement tool to assess the methodological quality of systematic reviews. BMC Med Res Methodol 2007;7:10.

10. Chung CP, Thompson JL, Koch GG, et al. Are American College of Rheumatology $50 \%$ response criteria superior to $20 \%$ criteria in distinguishing active aggressive treatment in rheumatoid arthritis clinical trials reported since 1997? A metaanalysis of discriminant capacities. Ann Rheum Dis 2006;65:1602-7.

11. Wells GA, Sultan SA, Chen L, et al. Indirect evidence: indirect treatment comparisons in meta-analysis. Ottawa $(\mathrm{ON})$ : Canadian Agency for Drugs and Technologies in Health; 2009. Available: www.cadth.ca/media/pdf/H0462_itc_tr_e.pdf (accessed 2009 Oct. 13).

12. Platt RW, Leroux BG, Breslow N. Generalized linear mixed models for metaanalysis. Stat Med 1999;18:643-54.

13. Osiri M, Suarez-Almazor ME, Wells GA, et al. Number needed to treat (NNT): implication in rheumatology clinical practice. Ann Rheum Dis 2003;62:316-21.

14. Blumenauer B, Judd M, Cranney A, et al. Etanercept for the treatment of rheumatoid arthritis. Cochrane Database Syst Rev 2003;(4):CD004525.

15. Blumenauer B, Judd M, Wells G, et al. Infliximab for the treatment of rheumatoid arthritis. Cochrane Database Syst Rev 2002;(3):CD003785.

16. Navarro-Sarabia F, Ariza-Ariza R, Hernandez-Cruz B, et al. Adalimumab for treating rheumatoid arthritis. Cochrane Database Syst Rev 2005;(3):CD005113.

17. Mertens M, Singh JA. Anakinra for rheumatoid arthritis. Cochrane Database Syst Rev 2009;(1):CD005121.

18. Lopez-Olivo M, Amezaga M, McGahan L, et al. Rituximab for rheumatoid arthritis. Cochrane Database Syst Rev 2009;(3):CD007356.

19. Maxwell L, Singh JA. Abatacept for rheumatoid arthritis. Cochrane Database Syst Rev 2009;(4)CD007277.

20. Arnett FC, Edworthy SM, Bloch DA, et al. The American Rheumatism Association 1987 revised criteria for the classification of rheumatoid arthritis. Arthritis Rheum 1988;31:315-24.

21. Singh JA, Christensen R, Wells G, et al. Biologics for rheumatoid arthritis: an overview of Cochrane reviews. Cochrane Database Syst Rev 2009;(4):CD007848.

22. Moreland LW, Alten R, Van den Bosch F, et al. Costimulatory blockade in patients with rheumatoid arthritis: a pilot, dose-finding, double-blind, placebo-controlled clinical trial evaluating CTLA-4Ig and LEA29Y eighty-five days after the first infusion. Arthritis Rheum 2002;46:1470-9.

23. Genovese MC, Becker JC, Schiff M, et al. Abatacept for rheumatoid arthritis refrac tory to tumor necrosis factor alpha inhibition. N Engl J Med 2005:353:1114-23.

24. Schiff MH, Pritchard C, Huffstutter JE, Rodriguez-Valverde V, Durez P, Zhou X, et al. The 6-month safety and efficacy of abatacept in patients with rheumatoid arthritis who underwent a washout after anti-TNF therapy or were directly switched to abatacept: the ARRIVE trial. Ann Rheum Dis 2009;68:1708-14.

25. Kremer JM, Westhovens R, Leon M, et al. Treatment of rheumatoid arthritis by selective inhibition of T-cell activation with fusion protein CTLA4Ig. $N$ Engl J Med 2003:349:1907-15.

26. Kremer JM, Genant HK, Moreland LW, et al. Effects of abatacept in patients with methotrexate-resistant active rheumatoid arthritis: A randomized trial. Ann Intern Med 2006;144:865-76.

27. Weinblatt M, Schiff M, Goldman A, et al. Selective costimulation modulation using abatacept in patients with active rheumatoid arthritis while receiving etanercept: a randomised clinical trial. Ann Rheum Dis 2007;66:228-34.

28. Bejarano V, Quinn M, Conaghan PG, et al. Effect of the early use of the anti-tumor necrosis factor adalimumab on the prevention of job loss in patients with early rheumatoid arthritis. Arthritis Rheum 2008;59:1467-74.

29. Breedveld FC, Weisman MH, Kavanaugh AF, et al. The PREMIER study: A multicenter, randomized, double-blind clinical trial of combination therapy with adalimumab plus methotrexate versus methotrexate alone or adalimumab alone in patients with early, aggressive rheumatoid arthritis who had not had previous methotrexate treatment. Arthritis Rheum 2006;54:26-37.

30. Furst DE, Schiff MH, Fleischmann RM, et al. Adalimumab, a fully human ant tumor necrosis factor-alpha monoclonal antibody, and concomitant standard concomitant standard antirheumatic therapy for the treatment of rheumatoid arthritis: Results of star (safety trial of adalimumab in rheumatoid arthritis). $J$ Rheumatol 2003;30:2563-71.

31. Keystone EC, Kavanaugh AF, Sharp JT, et al. Radiographic, clinical, and functional outcomes of treatment with adalimumab (a human anti-tumor necrosis factor monoclonal antibody) in patients with active rheumatoid arthritis receiving con- 
comitant methotrexate therapy: A randomized, placebo-controlled, 52-week trial. Arthritis Rheum 2004;50:1400-11.

32. Kim H, Lee S, Song Y, et al. A randomized, double-blind, placebo-controlled, phase III study of the human anti-tumor necrosis factor antibody adalimumab administered as subcutaneous injections in korean rheumatoid arthritis patients treated with methotrexate. APLAR J Rheumatol 2007;10:9-16.

33. Miyasaka N. Clinical investigation in highly disease-affected rheumatoid arthritis patients in japan with adalimumab applying standard and general evaluation: The change study. Mod Rheumatol 2008;18:252-62.

34. van de Putte LB, Atkins C, Malaise M, et al. Efficacy and safety of adalimumab as monotherapy in patients with rheumatoid arthritis for whom previous disease modifying antirheumatic drug treatment has failed. Ann Rheum Dis 2004;63:508-16.

35. Weinblatt ME, Keystone EC, Furst DE, et al. Adalimumab, a fully human antitumor necrosis factor alpha monoclonal antibody, for the treatment of rheumatoid arthritis in patients taking concomitant methotrexate: The armada trial. Arthritis Rheum 2003;48:35-45.

36. Cohen S, Hurd E, Cush J, et al. Treatment of rheumatoid arthritis with anakinra, a recombinant human interleukin-1 receptor antagonist, in combination with methotrexate: results of a twenty-four-week, multicenter, randomized, doubleblind, placebo-controlled trial. Arthritis Rheum 2002;46:614-24.

37. Cohen SB, Moreland LW, Cush JJ, et al. A multicentre, double blind, randomised, placebo controlled trial of anakinra (Kineret), a recombinant interleukin 1 receptor antagonist, in patients with rheumatoid arthritis treated with background methotrexate. Ann Rheum Dis 2004;63:1062-8.

38. Genovese MC, Cohen S, Moreland L, et al. Combination therapy with etanercept and anakinra in the treatment of patients with rheumatoid arthritis who have been treated unsuccessfully with methotrexate. Arthritis Rheum 2004;50:1412-9.

39. Moreland LW, Schiff MH, Baumgartner SW, et al. Etanercept therapy in rheumatoid arthritis. A randomized, controlled trial. Ann Intern Med 1999;130:478-86.

40. Weinblatt ME, Kremer JM, Bankhurst AD, et al. A trial of etanercept, a recombinant tumor necrosis factor receptor:Fc fusion protein, in patients with rheumatoid arthritis receiving methotrexate. N Engl J Med 1999;340:253-9.

41. Emery P, Breedveld FC, Hall S, et al. Comparison of methotrexate monotherapy with a combination of methotrexate and etanercept in active, early, moderate to severe rheumatoid arthritis (COMET): a randomised, double-blind, parallel treatment trial. Lancet 2008;372:375-82.

42. Klareskog L, van der Heijde D, de Jager JP, et al. Therapeutic effect of the combination of etanercept and methotrexate compared with each treatment alone in patients with rheumatoid arthritis: double-blind randomised controlled trial. Lancet 2004;363:675-81.

43. St Clair EW, van der Heijde DM, Smolen JS, et al. Combination of infliximab and methotrexate therapy for early rheumatoid arthritis: a randomized, controlled trial. Arthritis Rheum 2004;50:3432-43.

44. Lipsky PE, van der Heijde DM, St Clair EW, et al. Infliximab and methotrexate in the treatment of rheumatoid arthritis. Anti-Tumor Necrosis Factor Trial in Rheumatoid Arthritis with Concomitant Therapy Study Group. $N$ Engl J Med 2000;343:1594-602.

45. Quinn MA, Conaghan PG, O'Connor PJ, et al. Very early treatment with infliximab in addition to methotrexate in early, poor-prognosis rheumatoid arthritis reduces magnetic resonance imaging evidence of synovitis and damage, with sustained benefit after infliximab withdrawal: results from a twelve-month randomized, double-blind, placebo-controlled trial. Arthritis Rheum 2005;52:27-35.

46. Edwards JC, Szczepanski L, Szechinski J, et al. Efficacy of B-cell-targeted therapy with rituximab in patients with rheumatoid arthritis. N Engl J Med 2004;350:2572-81.
47. Emery P, Fleischmann R, Filipowicz-Sosnowska A, et al. The efficacy and safety of rituximab in patients with active rheumatoid arthritis despite methotrexate treatment: Results of a phase iib randomized, double-blind, placebo-controlled, doseranging trial. Arthritis Rheum 2006;54:1390-400.

48. Cohen SB, Emery P, Greenwald MW, et al. Rituximab for rheumatoid arthritis refractory to anti-tumor necrosis factor therapy: Results of a multicenter, randomized, double-blind, placebo-controlled, phase iii trial evaluating primary efficacy and safety at twenty-four weeks. Arthritis Rheum 2006;54:2793-806.

49. Bresnihan B, Alvaro-Gracia JM, Cobby M, et al. Treatment of rheumatoid arthritis with recombinant human interleukin-1 receptor antagonist. Arthritis Rheum 1998;41:2196-204.

50. Fleischmann RM, Schechtman J, Bennett R, et al. Anakinra, a recombinant human interleukin-1 receptor antagonist (r-metHuIL-1ra), in patients with rheumatoid arthritis: A large, international, multicenter, placebo-controlled trial. Arthritis Rheum 2003;48:927-34

51. Genovese MC, Becker JC, Schiff M, et al. Abatacept for rheumatoid arthritis refractory to tumor necrosis factor alpha inhibition. N Engl J Med 2005;353:1114-23.

52. Donahue KE, Gartlehner G, Jonas DE, et al. Systematic review: comparative effectiveness and harms of disease-modifying medications for rheumatoid arthritis. Ann Intern Med 2008;148:124-34.

53. Kristensen LE, Christensen R, Bliddal $\mathrm{H}$, et al. The number needed to treat for adalimumab, etanercept, and infliximab based on ACR50 response in three randomized controlled trials on established rheumatoid arthritis: a systematic literature review. Scand J Rheumatol 2007;36:411-7.

54. Alonso-Ruiz A, Pijoan JI, Ansuategui E, et al. Tumor necrosis factor alpha drugs in rheumatoid arthritis: systematic review and meta-analysis of efficacy and safety. BMC Musculoskelet Disord 2008;9:52.

55. Nixon RM, Bansback N, Brennan A. Using mixed treatment comparisons and meta-regression to perform indirect comparisons to estimate the efficacy of biologic treatments in rheumatoid arthritis. Stat Med 2007;26:1237-54.

56. Lee YH, Woo JH, Rho YH, et al. Meta-analysis of the combination of TNF inhibitors plus MTX compared to MTX monotherapy, and the adjusted indirect comparison of TNF inhibitors in patients suffering from active rheumatoid arthritis. Rheumatol Int 2008;28:553-9.

Correspondence to: Dr. Jasvinder A. Singh, Division of Rheumatology, Rm. 111R, Minneapolis VA Medical Center, 1 Veteran's Dr., Minneapolis MN 55417, USA; fax 612 725-2267; jasvinder.md@gmail.com

Cochrane reviews are regularly updated as new evidence emerges and in response to feedback. The Cochrane Library (www .thecochranelibrary.com) should be consulted for the most recent version of the review. Journal club and podcast of the Cochrane review is available at www.cochranejournalclub.com/biologics -for-rheumatoid-arthritis-clinical/. 